\title{
Investigation of the Radiological Risk of Farmlands and the Transfer Factor from Soil to Crops in Jalingo and Wukari L.G.A of Taraba State, Nigeria
}

\author{
Alexander A. Tyovenda ${ }^{1}$, John A. Ocheje ${ }^{2 *}$, Sombo Terver ${ }^{1}$, Effiong U. Uttah ${ }^{3}$ \\ ${ }^{1}$ Department of Physics, Federal University of Agriculture Makurdi, Makurdi, Benue State, Nigeria \\ ${ }^{2}$ Department of Pure and Applied Physics, Federal University Wukari, Wukari, Taraba State, Nigeria \\ ${ }^{3}$ Department of Physics, University of Uyo, Uyo, Akwa-Ibom State, Nigeria \\ Email: *ocheje@fuwukari.edu.ng
}

How to cite this paper: Tyovenda, A.A., Ocheje, J.A., Terver, S. and Uttah, E.U. (2022) Investigation of the Radiological Risk of Farmlands and the Transfer Factor from Soil to Crops in Jalingo and Wukari L.G.A of Taraba State, Nigeria. Journal of Environmental Protection, 13, 1-14. https://doi.org/10.4236/jep.2022.131001

Received: November 12, 2021

Accepted: January 2, 2022

Published: January 5, 2022

Copyright $\odot 2022$ by author(s) and Scientific Research Publishing Inc. This work is licensed under the Creative Commons Attribution International License (CC BY 4.0).

http://creativecommons.org/licenses/by/4.0/

\begin{abstract}
The activity concentrations of radionuclides, absorbed dose rate, excess lifetime cancer risk, and soil-to-plant transfer factor have been evaluated in soil and crop samples from Jalingo and Wukari Local Government Area of Taraba State, Nigeria. The activity concentrations were determined with the aid of High Purity Germanium detector. The absorbed dose and excess lifetime cancer risk were evaluated and forecasted for 60 years using the ResRad off-site model. The average activity concentration of ${ }^{40} \mathrm{~K},{ }^{232} \mathrm{Th}$, and ${ }^{238} \mathrm{U}$ in the soil samples were $633.13,141.15$, and $71.20 \mathrm{~Bq} \cdot \mathrm{kg}^{-1}$ respectively, for the Jalingo study area, and while that of the Wukari study area was; 199.21, 87.23, and $25.37 \mathrm{~Bq} \cdot \mathrm{kg}^{-1}$ respectively. The average soil-to-plant transfer factors for ${ }^{40} \mathrm{~K},{ }^{232} \mathrm{Th}$, and ${ }^{238} \mathrm{U}$ were $0.51,0.10$, and 0.27 respectively for the Jalingo study area while that of Wukari are $0.40,0.57$, and 0.74 respectively. The mean annual effective dose equivalent for the study area is higher than the world average of $0.07 \mathrm{mS} \cdot \mathrm{vy}^{-1}$. The excess lifetime cancer risk for the study areas has values that are higher than the safety limit. The ResRed model showed that direct radiation from the crops is the major contributor to excess cancer risk among other pathways. The radiological hazard indices reveal health risks to farmers, especially in the Jalingo area.
\end{abstract}

\section{Keywords}

Activity Concentration, Transfer Factor, Absorbed Dose, Excess Lifetime Cancer Risk 


\section{Introduction}

To assess the internal doses to humans from ingestion of radionuclides present in agricultural products, it is important to know the main processes which determine the uptake of radionuclides by plants in the environment. Farmlands are being contaminated with both natural and artificial radionuclides that continuously disintegrate to release nuclear particles. Natural radionuclides like ${ }^{238} \mathrm{U}$ and ${ }^{232} \mathrm{Th}$ including their daughter nuclides and non-series ${ }^{40} \mathrm{~K}$ are distributed by the geological and geochemical processes in the soils due to earth formation [1]. Internal exposure of humans is majorly attributed to food consumption which is due to radionuclides in the soil being transferred to food crops via uptake by crops [2].

Contamination of food by radionuclides may occur either by direct deposition of these radionuclides on the leaves of crops, stems, tubers, fruits, and roots or by absorption of radionuclides by plants (crop) from the soil. Transfer of these radionuclides from the contaminated region (soil, water, and air) is of great concern due to its long-term effect on humans and the environment. Nigeria as a developing nation is one among few countries of the world, that is faced with the challenge of indiscriminate dumping of refuge, the use of phosphate fertilizer to improve yield in farmlands, environmental pollution due to the use of explosives by Boko Haram and other terrorists on farmlands and communities, especially in the Northeast region where this research was carried out. Apart from the aforementioned, high background radiations are being noticed in farmland and dumpsites which could become treat human health through food chain [2]. Scientists across the globe are working hard to measure and analyze the radioactivity content of soils and their health implications to humans. Monitoring radioactivity concentration in farmland and its environment is of basic importance for human and environmental protection, but a faster and accurate method for the assessment of radioactivity is of great value [3]. This study aims to investigate the activity concentrations of natural radionuclides in locally grown food crops (yam, cassava, beans, and maize) in Jalingo and Wukari Local Government areas of Taraba state. These communities are the major agrarian communities of the state. The data got can be useful for the estimation of the internal radiation dose originating from the farmlands and the environment.

\section{Materials and Methods}

\subsection{Study Area}

In Taraba State, Northeast Nigeria, Jalingo is the State capital. It lays between $8^{\circ} 54^{\prime \prime}$ North latitude and $11^{\circ} 22^{\prime \prime}$ East longitude, and it is 351 meters high above sea level. It lies in the savanna-covered foothills of the Shebshi Mountains, about 25 miles $(40 \mathrm{~km})$ southeast of the River Benue. It has good fertile land for agricultural activities. On the other hand, Wukari is one of the major local government areas in Taraba state, it lies between latitude $7^{\circ} 51^{\prime} 0^{\prime \prime}$ North and Longitude $9^{\circ} 47^{\prime} 0 "$ East. The River Donga flows through the area and the Benue River forms 
a boundary with Nasarawa State to the northwest. A lot of commercial agricultural activity is being carried out in the area due to its vast rich land for farming. Figure 1 shows the Map of Taraba State indicating the study area.

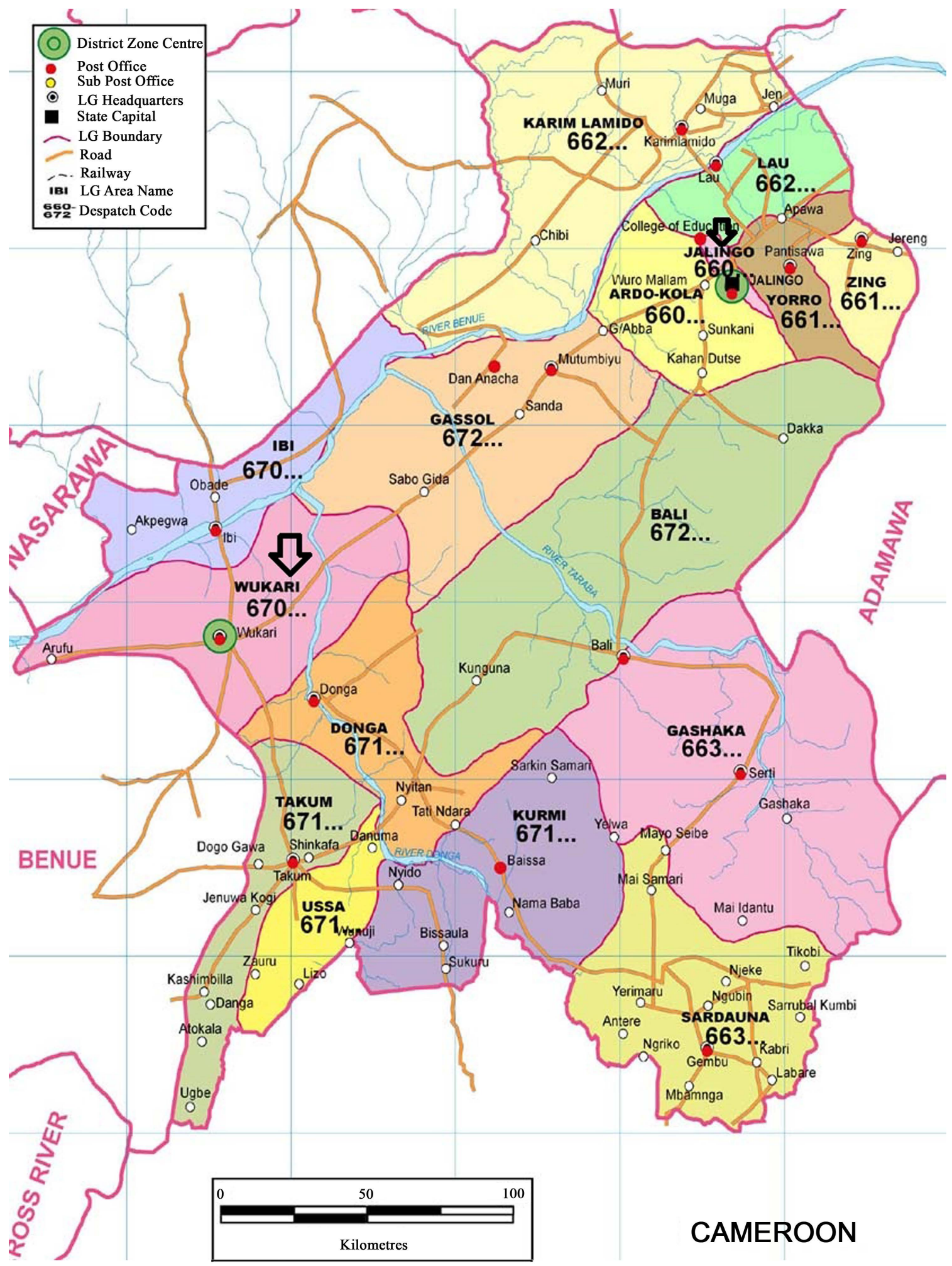

Figure 1. Map of Taraba State showing the study area. 


\subsection{Sample Collection and Preparation}

The crops cultivated within the region and soil samples were collected from farmland at harvest. Only the edible portions of the crops were collected for analysis. Due to high cost of analysis and time constrain few commercial farm lands were chosen within the study area. Ten samples of food crops were collected into a nylon bag and labeled from all farmlands selected within the study area. The yam and cassava tubers were washed under running water to get rid of the dust and soil particles. From the samples collected, the edible parts were taken separately and their net wet weight of $1000 \mathrm{~g}$ was collected. These samples were chopped and spread on a clean table for drying at room temperature. Samples were then dried, pounded, sieved, and homogenized to get a composite mixture. Drying was conducted for 2 weeks at room temperature and then in an oven at $110^{\circ} \mathrm{C}$ to get rid of the humidity and acquire a constant dry weight. Samples were homogenized by grinding and sieving through a $2 \mathrm{~mm}$ mesh. The ashes of the samples were then transferred to wash sample containers of specific sizes and were hermetically sealed. The samples were shelved for a minimum of one month to confirm the secular equilibrium between the isotopes, before gamma spectroscopy analyses.

\subsection{Radioactivity Measurement}

A high-resolution measurement system, consisting of a high purity germanium detector linked to a PC, was used for radioactivity measurement of the collected samples. The detector (model GCM-8023; serial number 9744, end cap diameter $78 \mathrm{~mm}$, length $69.8 \mathrm{~mm}$, expeditiously of $80 \%$, and energy resolution of two. 3 Kev Fwhm at $1332 \mathrm{KeV}$ peak of ${ }^{60} \mathrm{Co}$.) The detector was surrounded by a cylindrical lead shield. Gamma spectra were recorded and analyzed with Gamma vision software Genie 2000 (VI.3).

The sample was placed directly on the hpge detector and counted for 10 hours. The counting system exhibited high detection efficiency since the amount of pulses under a photograph peak is proportional to the intensity of the radiation reaching the detector volume. The count under the corresponding peaks within the energy spectrum was computed by subtracting the counts' thanks from Compton scattering of the upper peaks and other background sources from the peaks and the web area. The background counts within the detector assembly were determined using an empty container sealed under identical measurement conditions and having identical geometry because the container was used for the sample measurement. This procedure is essential due to the existence of natural radionuclides in building materials, cosmic rays entering the atmosphere, and the contribution from other radioactive sources which could be present within the laboratory.

\subsection{Transfer Factor}

Radionuclide uptake by plants from contaminated soil represents a key step of 
radionuclide input into the human food chain; this phenomenon is described by the soil-plant transfer factor, which is explained as the ratio between crop-specific activity and soil-specific activity. Plants are the primary recipients of radioactive contamination to the soil following atmospheric release of a radionuclide. In the study of routine or accidental release of radionuclides, the transfer factor (TF) can be valuable to evaluate the impact on the environment of many important agricultural products. For other areas and particularly developing countries, the knowledge of Transfer Factors (TFs) particularly in most farm land is still lacking [2] [3]. The soil-to-plant transfer factor is employed in concert with the foremost important parameters in the environmental assessment needed for nuclear facilities. This parameter is essential for environmental transfer models which are useful within the prediction of radionuclide concentrations in agriculture crops for estimating dose intake by man [4].

The soil-to-plant Tfs of the plant to the soil were evaluated using the expression [5].

$$
\mathrm{TF}=\frac{\mathrm{CRC}}{\mathrm{CRS}}
$$

where CRC-activity concentration of radionuclides in crops in $\mathrm{Bq} \cdot \mathrm{kg}^{-1}$ dry and CRS-activity concentration of radionuclides in the soil in Bq. $\mathrm{kg}^{-1}$ dry.

\subsection{Absorbed Dose Rate (AD)}

The amount of absorbed radiation dose for the collected samples was evaluated using the expression.

$$
\mathrm{AD}\left(\mathrm{nGy} \cdot \mathrm{h}^{-1}\right)=0.462 A_{u}+0.604 A_{T h}+0.0417 A_{k}
$$

where, $A_{u}, A_{T h}$, and $A_{k}$ are the activity concentrations of ${ }^{238} \mathrm{U},{ }^{232} \mathrm{Th}$, and ${ }^{40} \mathrm{~K}$ of the samples, respectively, and conversion factors of $0.462 \mathrm{nGyh}^{-1} / \mathrm{Bq} \cdot \mathrm{kg}^{-1}, 0.604$ $\mathrm{nGyh}^{-1} / \mathrm{Bq} \cdot \mathrm{kg}^{-1}$ and $0.0417 \mathrm{nGyh}{ }^{-1} / \mathrm{Bq} \cdot \mathrm{kg}^{-1}$ for ${ }^{238} \mathrm{U},{ }^{232} \mathrm{Th}$, and ${ }^{40} \mathrm{~K}$ respectively [3].

\subsection{Annual Effective Dose Rate (AEDR)}

The annual effective dose rate of the considered population was evaluated using the conversion coefficient from the absorbed dose in the air to the effective dose given as $\left(0.7 \mathrm{~Sv} \cdot \mathrm{Gy}^{-1}\right)$ and taking into consideration the outdoor occupancy factor (0.2), and the indoor occupancy factor (0.8) (12). The outdoor AEDR is obtained from the expression (11):

$$
\text { Outdoors } \operatorname{AED}\left(\mathrm{mSv} \cdot \mathrm{y}^{-1}\right)=\mathrm{AD}\left(\mathrm{nGy} \cdot \mathrm{h}^{-1}\right) \times(8760 \mathrm{~h}) \times\left(0.7 \mathrm{SvG}^{-1}\right) \times 0.2
$$

The total annual effective dose rate (AED) is the sum of the annual effective dose rate of natural radionuclides and the annual effective dose rate of radionuclides in $(\mu \mathrm{Sv} / \mathrm{y})$.

The farmers spend more time on their farms; they spend about 5 to 7 hours of their day on the farm. This gave a factor of $5 / 24=0.2$ for the outdoor occupancy factor [6]. 


\subsection{Radium Equivalent Activity}

The radium equivalent activity is used to evaluate the radiation doses accruing from ${ }^{226} \mathrm{Ra}$, ${ }^{232} \mathrm{Th}$, and ${ }^{40} \mathrm{~K}$. It is one of the most used hazard indices in radiation protection assessment [7] [8]. The radium equivalent activity is estimated on the concept that $370 \mathrm{~Bq} \cdot \mathrm{kg}^{-1}$ of ${ }^{226} \mathrm{Ra},{ }^{259} \mathrm{~Bq} \cdot \mathrm{kg}^{-1}$ of ${ }^{232} \mathrm{Th}$, and $4810 \mathrm{~Bq} \cdot \mathrm{kg}^{-1}$ of ${ }^{40} \mathrm{~K}$ produce identical gamma dose rates. Radium equivalent activities are often calculated from relation [8]:

$$
R a_{e q}=0.077 A_{k}+A_{R a}+1.43 A_{T h}
$$

where $A_{R a}$ is the activity concentration of ${ }^{226} \mathrm{Ra}$ in $\mathrm{Bq} \cdot \mathrm{kg}^{-1}, A_{T h}$ is the activity concentration of ${ }^{232} \mathrm{Th}$ in Bq. $\mathrm{kg}^{-1}$ and $A_{K}$ is the activity concentration of ${ }^{40} \mathrm{~K}$ in $\mathrm{Bq} \cdot \mathrm{kg}^{-1}$. Internal radiation hazard index $\left(H_{\text {in }}\right)$, The internal radiation hazard in$\operatorname{dex}\left(H_{i n}\right)$, is employed to scale back the most permissible concentration of ${ }^{226} \mathrm{Ra}$ to half the values appropriate for external exposure alone. The radionuclide radon-222 which is a progeny of ${ }^{226} \mathrm{Ra}$ poses threats to the respiratory organs when absorbed in large quantities within the indoor air [9]. To own safe farmland for agricultural purposes, the maximum value of the internal hazard index should be less than or equal to unity. The internal exposure to ${ }^{222} \mathrm{Rn}$ and its radioactive daughters will be controlled by the internal hazard index. The internal hazard index is calculated as:

$$
H_{\text {int }}=\frac{A_{k}}{4810}+\frac{A_{u}}{185}+\frac{A_{T h}}{259} \leq 1
$$

$A_{R a}, A_{u}$ and $A_{K}$ are the specific activity concentrations of ${ }^{226} \mathrm{Ra},{ }^{232} \mathrm{Th}$, and ${ }^{40} \mathrm{~K}$ in Bq. $\mathrm{kg}^{-1}$, respectively. External radiation hazard index $\left(H_{e x}\right)$ is the estimation of the external hazard index $\left(H_{e x}\right)$ for the assessment of the suitability of any environment for dwelling or other occupational purposes. The external hazard index of electromagnetic (gamma) radiation is estimated using:

$$
H_{\text {ext. }}=\frac{A_{k}}{4810}+\frac{A_{u}}{370}+\frac{A_{T h}}{259} \leq 1
$$

where, $A_{R a}, A_{T h}$, and $A_{K}$ are the specific activity concentrations of ${ }^{226} \mathrm{Ra},{ }^{232} \mathrm{Th}$, and ${ }^{40} \mathrm{~K}$ in $\mathrm{Bq} / \mathrm{kg}$, respectively. The external hazard index is gotten from the expression of the radium equivalent through the assertion that the maximum permissible value corresponds to the upper limit of $R a_{e q}(370 \mathrm{~Bq} / \mathrm{kg})$, therefore the external dose rate does not exceed $1.5 \mathrm{mGy} / \mathrm{y}$. To reduce the external gamma dose to $1.5 \mathrm{mGy} / \mathrm{y}$, for the radiation hazard to be negligible or insignificant, the external hazard index must conform to the criterion of $H_{\text {ext. }} \leq 1$.

\section{Results and Discussion}

The evaluation of radioactivity was carried out in ten farmlands of the study area to estimate the activity concentration in soil and crops, soil to plant transfer factor, radiological indices, and cancer risk probability due to continuous exposure to ionizing radiation as a result of ingestion and inhalation of radionuclides from farmlands, ambient radiation, use of inorganic fertilizer and agrochemicals. 
The tables and graphical representations of the data are provided in the respective sections. RESRAD computer model was used to forecast the absorbed dose rate and excess lifetime cancer risk for sixty years.

\subsection{Radioactivity Concentration of $238 \mathrm{U},{ }^{232} \mathrm{Th}$, and ${ }^{40} \mathrm{~K}$}

The soil activity concentrations of ${ }^{238} \mathrm{U}$ in soils of Jalingo were found to be within the range of 20.2 to $127.6 \mathrm{~Bq} / \mathrm{kg}$ (Table 1). The average value of ${ }^{238} \mathrm{U}$ in Jalingo farm soils was found to be $71.20 \pm 0.05 \mathrm{~Bq} / \mathrm{kg}$, which is higher than the world average of $35 \mathrm{~Bq} / \mathrm{kg}$ [10] [11] [12] [13] [14] The activity concentration of ${ }^{232} \mathrm{Th}$ in soils of the area was 85.56 to $259.09 \mathrm{~Bq} / \mathrm{kg}$, with an average value of 141.15 $\mathrm{Bq} / \mathrm{kg}$. Virtually the soils from the farmlands in Jalingo contained relatively high levels of ${ }^{232} \mathrm{Th}$ (Figure 2) compared to the world average value of $30 \mathrm{~Bq} / \mathrm{kg}$ [11] [14]. The activity concentration of ${ }^{40} \mathrm{~K}$ ranged from 332 to $1252 \mathrm{~Bq} / \mathrm{kg}$, with an average value of $633.13 \mathrm{~Bq} / \mathrm{kg}$, which is relatively much higher than the world average of $400 \mathrm{~Bq} / \mathrm{kg}$ [14].

Radionuclide activity concentration of ${ }^{238} \mathrm{U},{ }^{232} \mathrm{Th}$, and ${ }^{40} \mathrm{~K}$ was also measured in harvested crops from each farmland corresponding to the soils collected from Jalingo L.G.A as shown in Table 2. The activity concentration of ${ }^{238} \mathrm{U}$ in yam and cassava tubers varied between 10.2 and $20.16 \mathrm{~Bq} / \mathrm{kg}$ and that of cereal crops (maize and beans) varied between 7.04 and 12.06. The maximum activity was found in tuber crops. The activity concentrations of ${ }^{232} \mathrm{Th}$ ranged from 8.35 to

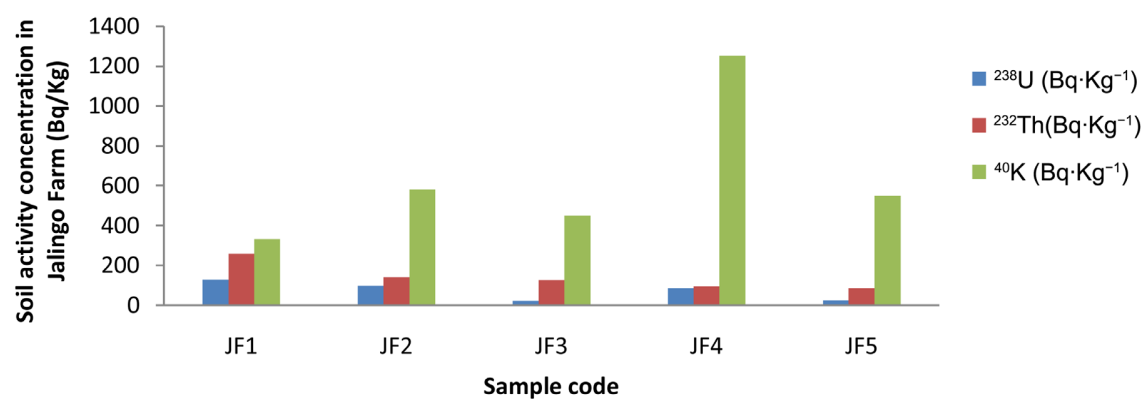

Figure 2. The activity level and distribution of ${ }^{238} \mathrm{U},{ }^{232} \mathrm{Th}$, and ${ }^{40} \mathrm{~K}$ in Jalingo farm.

Table 1. Soil activity concentration in Jalingo and Wukari LGA of Taraba State.

\begin{tabular}{|c|c|c|c|c|c|c|c|}
\hline $\begin{array}{l}\text { Sample } \\
\text { code }\end{array}$ & $\begin{array}{c}{ }^{238} \mathrm{U} \\
\left(\mathrm{Bq} \cdot \mathrm{Kg}^{-1}\right)\end{array}$ & $\begin{array}{c}{ }^{232} \mathrm{Th} \\
\left(\mathrm{Bq} \cdot \mathrm{Kg}^{-1}\right)\end{array}$ & $\begin{array}{c}{ }^{40} \mathrm{~K} \\
\left(\mathrm{~Bq} \cdot \mathrm{Kg}^{-1}\right)\end{array}$ & $\begin{array}{l}\text { Sample } \\
\text { code }\end{array}$ & $\begin{array}{c}{ }^{238} \mathrm{U} \\
\left(\mathrm{Bq} \cdot \mathrm{Kg}^{-1}\right)\end{array}$ & $\begin{array}{c}{ }^{232} \mathrm{Th} \\
\left(\mathrm{Bq} \cdot \mathrm{Kg}^{-1}\right)\end{array}$ & $\begin{array}{c}{ }^{40} \mathrm{~K} \\
\left(\mathrm{~Bq} \cdot \mathrm{Kg}^{-1}\right)\end{array}$ \\
\hline WF1 & 45.67 & 58.99 & 100.7 & JF1 & 127.6 & 259.09 & 332.17 \\
\hline WF2 & 47.35 & 157.12 & 164.44 & JF2 & 98.12 & 140.34 & 580.64 \\
\hline WF3 & 10.55 & 64.94 & 340.24 & JF3 & 20.2 & 126.11 & 450.45 \\
\hline WF4 & 8.06 & 94.67 & 140.26 & JF4 & 84.62 & 94.64 & 1252.05 \\
\hline WF5 & 15.2 & 60.44 & 250.4 & JF5 & 25.45 & 85.56 & 550.35 \\
\hline Average & $25.37 \pm 8.71$ & $87.23 \pm 18.64$ & $199.21 \pm 42.95$ & Average & $71.20 \pm 20.95$ & $141.14 \pm 31.14$ & $633.13 \pm 160.72$ \\
\hline
\end{tabular}

Note: WF, Wukari farmland; JF, Jalingo farmland. 
Table 2. Crop activity concentration in Jalingo and Wukari LGA of Taraba State.

\begin{tabular}{|c|c|c|c|c|c|c|c|}
\hline $\begin{array}{c}\text { Sample } \\
\text { code }\end{array}$ & $\begin{array}{c}{ }^{238} \mathrm{U} \\
\left(\mathrm{Bq} \cdot \mathrm{Kg}^{-1}\right)\end{array}$ & $\begin{array}{c}{ }^{232} \mathrm{Th} \\
\left(\mathrm{Bq} \cdot \mathrm{Kg}^{-1}\right)\end{array}$ & $\begin{array}{c}{ }^{40} \mathrm{~K} \\
\left(\mathrm{~Bq} \cdot \mathrm{Kg}^{-1}\right)\end{array}$ & $\begin{array}{c}\text { Sample } \\
\text { code }\end{array}$ & $\begin{array}{c}{ }^{238} \mathrm{U} \\
\left(\mathrm{Bq} \cdot \mathrm{Kg}^{-1}\right)\end{array}$ & $\begin{array}{c}{ }^{232} \mathrm{Th} \\
\left(\mathrm{Bq} \cdot \mathrm{Kg}^{-1}\right)\end{array}$ & $\begin{array}{c}{ }^{40} \mathrm{~K} \\
\left(\mathrm{~Bq} \cdot \mathrm{Kg}^{-1}\right)\end{array}$ \\
\hline JMF1 & 8.11 & 10.66 & 168.95 & WYF1 & 8.74 & 40.44 & 19.09 \\
\hline JYF2 & 20.16 & 16.3 & 250.64 & WYF2 & 12.08 & 95.32 & 70.63 \\
\hline JMF3 & 12.06 & 12.35 & 110.46 & WYF3 & 17.4 & 26.88 & 198.27 \\
\hline JBF4 & 7.04 & 15.67 & 450.52 & WMF4 & 8.6 & 50.66 & 85.68 \\
\hline JYF5 & 10.2 & 8.35 & 550.3 & WMF5 & 8.2 & 35.45 & 40.2 \\
\hline Average & $11.51 \pm 2.33$ & $12.67 \pm 1.50$ & $306.17 \pm 83.86$ & Average & $11.00 \pm 1.74$ & $49.75 \pm 12.02$ & $82.77 \pm 31.12$ \\
\hline
\end{tabular}

Note: JMF, Jalingo maize farm; JYF, Jalingo yam farm; JBF, Jalingo beans farm; WMF, Wukari maize farm; WYF, Wukari yam farm.

16.3 $\mathrm{Bq} / \mathrm{Kg}$ for tubers and 10.66 to $15.7 \mathrm{~Bq} / \mathrm{Kg}$ for cereal crops. The activity concentration of ${ }^{40} \mathrm{~K}$ ranged from 168.95 to $550.3 \mathrm{~Bq} / \mathrm{kg}$ for tubers and 110.46 to $450.52 \mathrm{~Bq} / \mathrm{kg}$ for cereal crops. On average, the activity concentrations of radionuclides in tubers were higher than those of cereal crops in almost the farmland in Jalingo. This may not be unconnected with the fact that tubers spend more time in soil to mature compared to cereal crops, the high ambient radiation absorbed by crops, and the inorganic fertilizer that is being applied by farmers at the root region of plants, hence the root gets it first before the other parts of the crops. The same thing applies if the radionuclides are naturally deposited in the soil. This is similar to the findings of [2] on the activity concentration of radionuclides of some crops in Kogi State.

Similarly, the soil activity concentrations of ${ }^{238} \mathrm{U}$ in Wukari were within the range of 8.06 to $45.67 \mathrm{~Bq} / \mathrm{kg}$, with an average of $25.37 \pm 8.71 \mathrm{~Bq} / \mathrm{kg}$, which is within the safety limit for the world average of $35 \mathrm{~Bq} / \mathrm{kg}$ [14]. The activity concentration of ${ }^{232} \mathrm{Th}$ in soils of Wukari farm soils was 60.44 to $157.12 \mathrm{~Bq} / \mathrm{kg}$, with an average value of $87.23 \pm 18.64 \mathrm{~Bq} / \mathrm{kg}$, which is almost three times the world average value of $30 \mathrm{~Bq} / \mathrm{kg}$ [14], this shows there is a high concentration of ${ }^{232} \mathrm{Th}$ in the area (Figure 3). The activity concentration of ${ }^{40} \mathrm{~K}$ ranged from 100.70 to $340.24 \mathrm{~Bq} / \mathrm{kg}$ with an average of $199.21 \pm 42.95 \mathrm{~Bq} / \mathrm{kg}$. The corresponding activity concentrations in crops selected from the Wukari farm were also evaluated as shown in Table 2. The activity concentration of ${ }^{238} \mathrm{U}$ in yam and cassava tubers varied between 8.20 and $17.40 \mathrm{~Bq} / \mathrm{kg}$ and that of maize crops varied between 8.60 and 8.74 . The maximum activity concentration was found in tuber crops. The activity concentrations of ${ }^{232} \mathrm{Th}$ ranged from 26.88 to $95.32 \mathrm{~Bq} / \mathrm{Kg}$ for tubers and 40.44 to $50.66 \mathrm{~Bq} / \mathrm{Kg}$ for cereal crops. The activity concentration of ${ }^{40} \mathrm{~K}$ ranged from 40 to $198.27 \mathrm{~Bq} / \mathrm{kg}$ for tubers and 19.09 to $85.68 \mathrm{~Bq} / \mathrm{kg}$ for cereal crops. Again, the activity concentrations in tubers were higher than those of cereal crops in most of the farms evaluated.

The results available from the two farms shows that the level of radionuclide present in the soil does not automatically transfer to food crops, several factors 


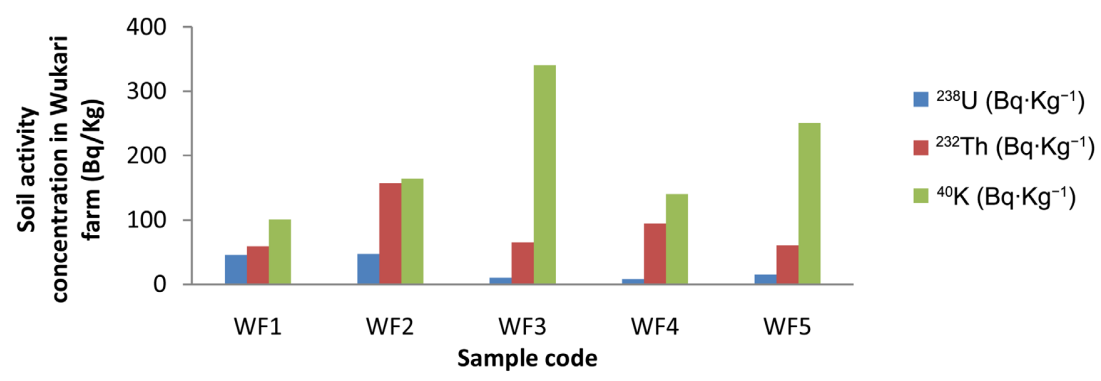

Figure 3. The activity level and distribution of ${ }^{238} \mathrm{U},{ }^{232} \mathrm{Th}$, and ${ }^{40} \mathrm{~K}$ in Wukari farm.

enhance the absorption or uptake of radionuclides into crops as already highlighted above. Some areas with high activity concentrations in soil have low activity concentrations in crops, particularly for ${ }^{238} \mathrm{U}$ and ${ }^{232} \mathrm{Th}$. Though ${ }^{40} \mathrm{~K}$ differs in this assertion in some locations and that is because ${ }^{40} \mathrm{~K}$ plays a very important role in terms of plant nutrients and ${ }^{40} \mathrm{~K}$ also helps in the regulation of water in the plant. Hence, its high uptake by plants.

\subsection{Transfer Factor (TF) of ${ }^{238} \mathrm{U},{ }^{232} \mathrm{Th}$, and ${ }^{40} \mathrm{~K}$ from Soil to Crops}

In Jalingo farms, the value of transfer factor for ${ }^{40} \mathrm{~K}$ leads other radionuclides in the area with the following average values $0.270,0.1037$, and 0.5090 for ${ }^{238} \mathrm{U}$, ${ }^{232} \mathrm{Th}$, and ${ }^{40} \mathrm{~K}$ respectively (Table 3 ). The high value of ${ }^{40} \mathrm{~K}$ could be a result of the high usage of inorganic fertilizer (NPK) and agrochemical in the area; this is because most of these farmers apply the inorganic fertilizers directly at the root region of crops and in high quantity. The high uptake of ${ }^{40} \mathrm{~K}$ by crops may also be attributed to the essential nutrient properties of potassium to plants and the nature of the soil. The high TF values, recorded for ${ }^{232} \mathrm{Th}$ and ${ }^{238} \mathrm{U}$, could be due to the long deposit of radionuclides over the years, type of soil, $\mathrm{pH}$ level, and the high ambient radiation of the zone (Table 4). The activities of bandits and terrorists in the zone could have accounted for the high value too. This is because Taraba state in the northeast could have also had a fair share of the use of explosives by terrorists to attack and destroy houses and farmlands in the area. The use of these explosives over the years by these terrorists in the area could have deposited radionuclides to farmlands and crops as well and in turn, contributed to the level of TF in the area.

On the other hand, the case of the Transfer factor in Wukari differs greatly from Jalingo, the average transfer factor for Wukari is $0.7405,0.5656$, and 0.3946 (Table 3) for ${ }^{238} \mathrm{U},{ }^{232} \mathrm{Th}$, and ${ }^{40} \mathrm{~K}$ respectively. The $\mathrm{TF}$ of ${ }^{238} \mathrm{U}$ leads in the area followed by ${ }^{232} \mathrm{Th}$ and ${ }^{40} \mathrm{~K}$. The high value of TF for ${ }^{238} \mathrm{U}$ might be connected to the nature of the soil, the $\mathrm{pH}$ level of the area, the high ambient radiation of the area, and high organic matter content of the area (Table 5), this is in agreement with work done by other researchers [7] [8] [10] [11] [12] [13].

The excess lifetime cancer risk was also evaluated and the result is found in Table 6. The values obtained for both Jalingo and Wukari are above the world value of $0.229 \times 10^{-3}$ [14]. Jalingo has an average value of $0.7287 \times 10^{-3}$ (Table $6)$, which is two times the world average value. 
A. A. Tyovenda et al.

Table 3. Transfer factor (TF) from soil to crops in Jalingo and Wukari L.G.A.

\begin{tabular}{cccccccc}
\hline $\begin{array}{c}\text { Sample } \\
\text { code }\end{array}$ & $\begin{array}{c}{ }^{238} \mathrm{U} \\
\left(\mathrm{Bq} \cdot \mathrm{Kg}^{-1}\right)\end{array}$ & $\begin{array}{c}{ }^{232} \mathrm{Th} \\
\left(\mathrm{Bq} \cdot \mathrm{Kg}^{-1}\right)\end{array}$ & $\begin{array}{c}{ }^{40} \mathrm{~K} \\
\left(\mathrm{~Bq} \cdot \mathrm{Kg}^{-1}\right)\end{array}$ & $\begin{array}{c}\text { Sample } \\
\text { code }\end{array}$ & $\begin{array}{c}{ }^{238} \mathrm{U} \\
\left(\mathrm{Bq} \cdot \mathrm{Kg}^{-1}\right)\end{array}$ & $\begin{array}{c}{ }^{232} \mathrm{Th} \\
\left(\mathrm{Bq} \cdot \mathrm{Kg}^{-1}\right)\end{array}$ & $\begin{array}{c}{ }^{40} \mathrm{~K} \\
\left(\mathrm{~Bq} \cdot \mathrm{Kg}^{-1}\right)\end{array}$ \\
\hline JF1 & 0.0636 & 0.0411 & 0.5086 & $\mathrm{WF} 1$ & 0.1914 & 0.6855 & 0.1896 \\
JF2 & 0.2055 & 0.1162 & 0.4317 & $\mathrm{WF} 2$ & 0.2551 & 0.6067 & 0.4295 \\
JF3 & 0.5970 & 0.0979 & 0.2452 & WF3 & 1.6493 & 0.4139 & 0.5827 \\
JF4 & 0.0832 & 0.1656 & 0.3598 & WF4 & 1.0670 & 0.5351 & 0.6109 \\
JF5 & 0.4008 & 0.0976 & 1.0000 & WF5 & 0.5395 & 0.5865 & 0.1605 \\
Average & $0.270 \pm 0.10$ & $0.104 \pm 0.02$ & $0.509 \pm 0.13$ & Average & $0.743 \pm 0.27$ & $0.566 \pm 0.05$ & $0.395 \pm 0.10$ \\
\hline
\end{tabular}

Note: JF, Jalingo farm; WF, Wukari farm.

Table 4. Surrounding ambient radiation in Jalingo L.G.A.

\begin{tabular}{|c|c|c|c|c|c|}
\hline $\begin{array}{l}\text { NO. of } \\
\text { readings }\end{array}$ & $\begin{array}{c}\mathrm{JF} 1 \\
\left(\mathrm{mS} \cdot \mathrm{vy}^{-1}\right)\end{array}$ & $\begin{array}{c}\mathrm{JF} 2 \\
\left(\mathrm{mS} \cdot \mathrm{vy}^{-1}\right)\end{array}$ & $\begin{array}{c}\mathrm{JF} 3 \\
\left(\mathrm{mS} \cdot \mathrm{vy}^{-1}\right)\end{array}$ & $\begin{array}{c}\mathrm{JF} 4 \\
\left(\mathrm{mS} \cdot \mathrm{vy}^{1}\right)\end{array}$ & $\begin{array}{c}\text { JF5 } \\
\left(\mathrm{mS} \cdot \mathrm{vy}^{1}\right)\end{array}$ \\
\hline 1 & 2.0162 & 1.7532 & 1.5779 & 1.5779 & 1.2340 \\
\hline 2 & 1.9285 & 2.0162 & 2.2792 & 2.1915 & 2.0081 \\
\hline 3 & 1.5779 & 1.1396 & 2.4545 & 1.4026 & 1.8540 \\
\hline 4 & 1.8409 & 1.5779 & 1.4026 & 1.7532 & 0.8752 \\
\hline 5 & 1.4026 & 2.1038 & 1.6655 & 1.9285 & 1.0321 \\
\hline Average & $1.75 \pm 0.11$ & $1.7181 \pm 0.17$ & $0.02 \pm 0.002$ & $1.77 \pm 0.14$ & $1.40 \pm 0.23$ \\
\hline
\end{tabular}

Note: JF, Jalingo farm.

Table 5. Physiochemical properties of Jalingo and Wukari farmlands.

\begin{tabular}{cccccc}
\hline $\begin{array}{c}\text { Sample } \\
\text { locations }\end{array}$ & $\begin{array}{c}\text { Clay } \\
(\%)\end{array}$ & $\begin{array}{c}\text { Silt } \\
(\%)\end{array}$ & $\begin{array}{c}\text { Sand } \\
(\%)\end{array}$ & $\begin{array}{c}\mathrm{pH} \\
\text { level }\end{array}$ & $\begin{array}{c}\text { Organic matter } \\
(\%)\end{array}$ \\
\hline Jalingo & $15-22$ & $17-28$ & $65-82$ & $5.8-7.8$ & $0.62-0.84$ \\
Wukari & $15-27$ & $20-40$ & $65-70$ & $5.8-6.9$ & $0.48-1.52$ \\
\hline
\end{tabular}

Table 6. Radiological hazard indices of soil samples from farmlands.

\begin{tabular}{ccccccc}
\hline Locations & $\begin{array}{c}\text { Absorbed dose } \\
(\mathrm{nGy} / \mathrm{h})\end{array}$ & $\begin{array}{c}\text { AEDR } \\
(\mathrm{mSv})\end{array}$ & $\begin{array}{c}\text { Raeq } \\
(\mathrm{Bq} / \mathrm{kg})\end{array}$ & $H_{\text {ext. }}$ & $H_{\text {int. }}$ & $\begin{array}{c}\text { ELTCR } \\
\left(\times 10^{-3}\right)\end{array}$ \\
\hline Jalingo & 169.6849 & 0.2082 & 375.5057 & 1.0142 & 1.2937 & 0.7287 \\
Wukari & 84.0591 & 0.1031 & 191.2352 & 0.5165 & 0.6422 & 0.3610 \\
\hline
\end{tabular}

\subsection{RESRAD Model}

The total radionuclide Absorbed dose in 60 years as forecasted by the RESRAD computer model for Jalingo and Wukari farms was $2.5188 \mathrm{mSv} / \mathrm{y}$ (Figure 4(a)) and $3.4296 \mathrm{mSv} / \mathrm{y}$ (Figure 4(b)), and there the corresponding maximum total cancer risk for all the pathways was $5.465 \times 10^{-3}$ (Figure $4(\mathrm{c})$ ) at year 32 years 
DOSE: All Nuclides Summed, Component Pathways in Jalingo L.G.A

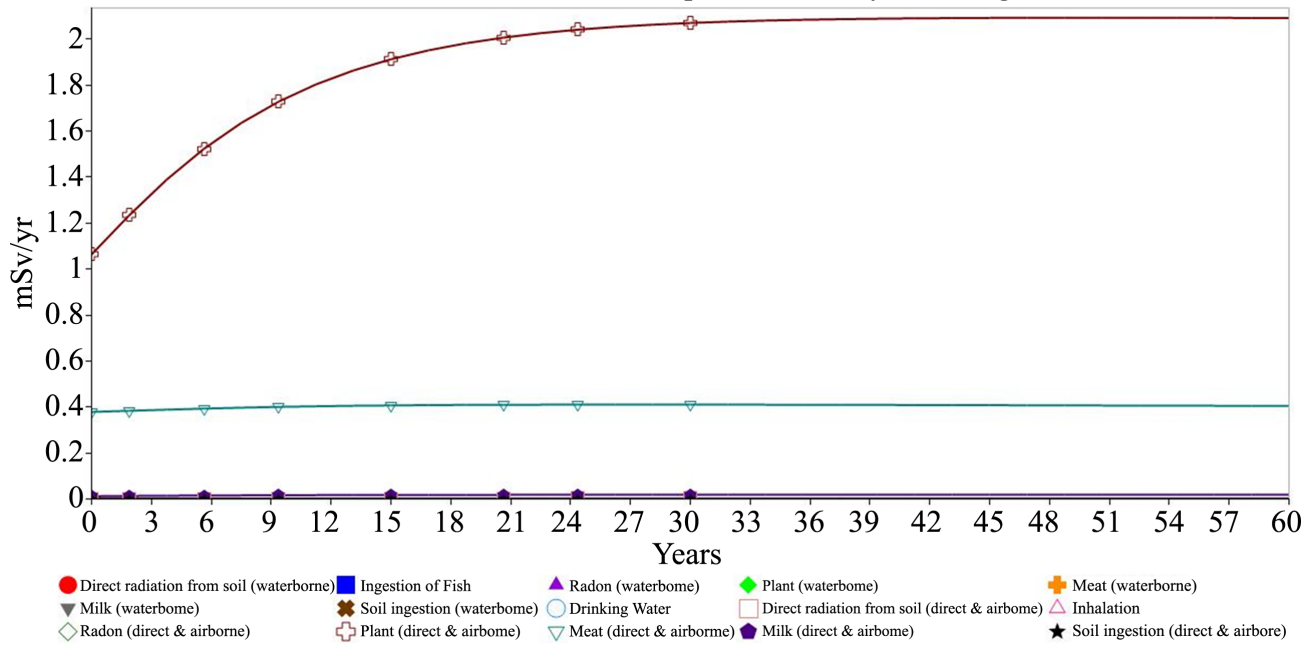

(a)

EXCESS CANCER RISK: All Nuclides Summed, Component Pathways in Jalingo L.G.A

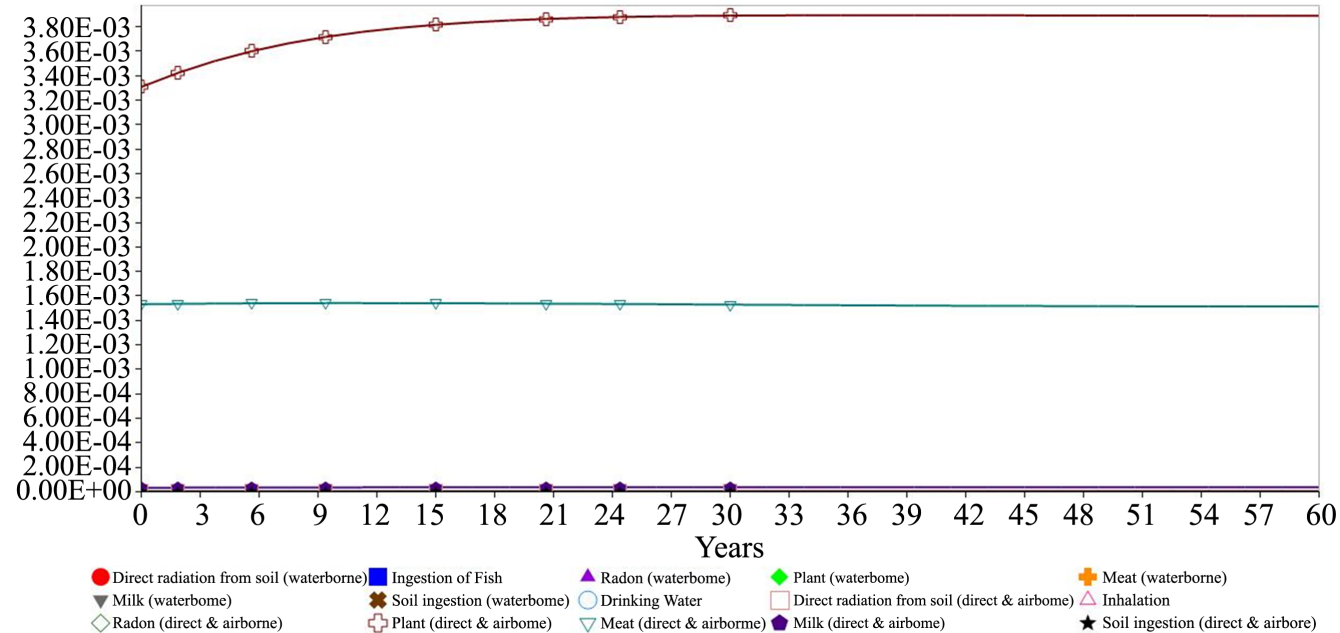

(b)

DOSE: All Nuclides Summed, Component Pathways in Jalingo L.G.A

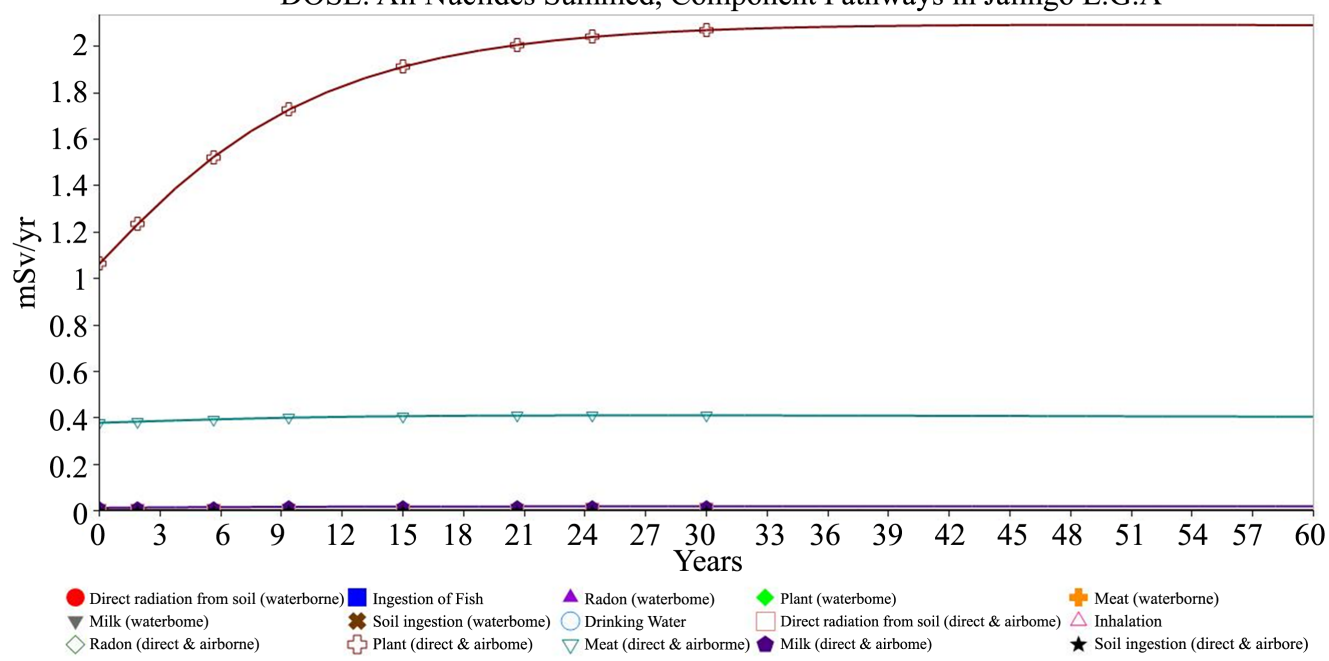

(c) 
EXCESS CANCER RISK: All Nuclides Summed, Component Pathways in Jalingo L.G.A

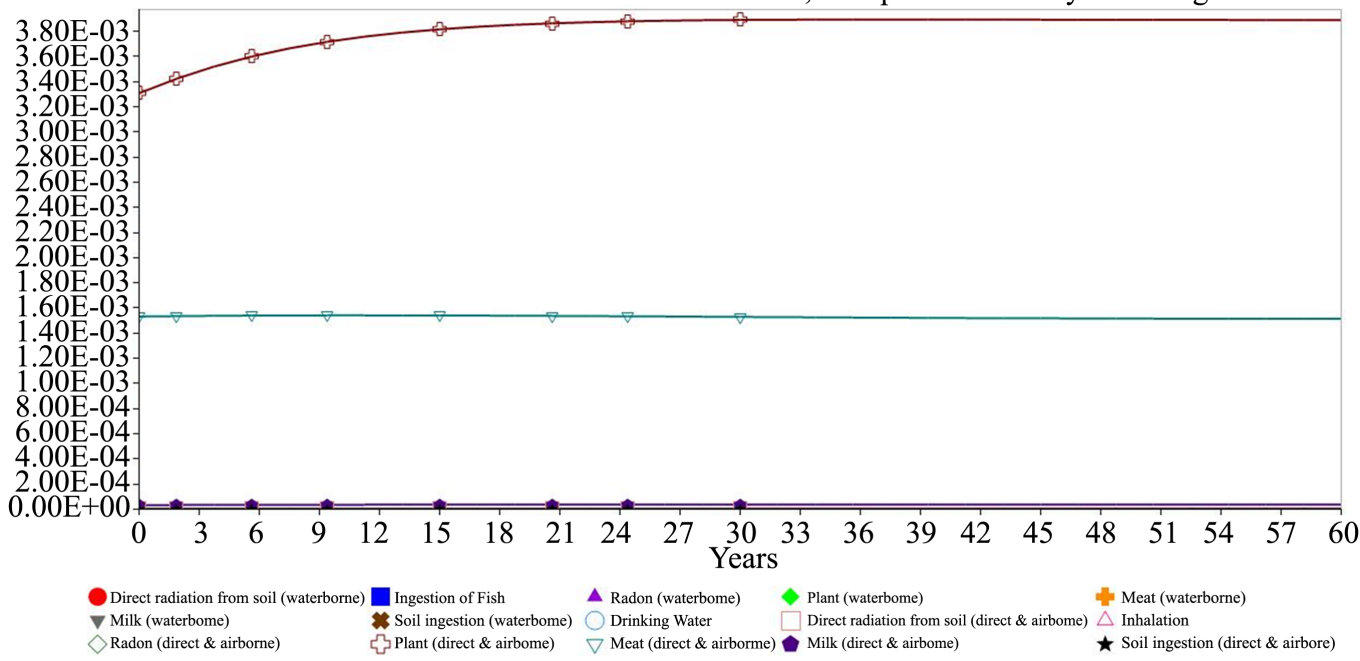

(d)

Figure 4. (a) Jalingo total component pathway radionuclide dose; (b) Jalingo total component pathway excess cancer risk; (c) Jalingo total component pathway radionuclide dose; (d) Jalingo total component pathway excess cancer risk.

and $4.7 \times 10^{-3}$ at 51 (Figure $4(\mathrm{~d})$ ) years respectively. This is illustrated in Figures 2(a)-(d). The World Health Organization considers acceptable for regulatory purposes a cancer risk in the range of $1 \times 10^{-6}$ to $1 \times 10^{-4}(2)$. Analyses of the model reveal that the water-independent pathway is the most significant in calculating the excess cancer risk. In this pathway, the cancer risk is largely caused by direct radiation from the plant (direct and airborne), followed by soil (direct and airborne) and then inhalation followed by soil ingestion.

\subsection{Radiological Indices}

The absorbed dose rate, annual effective dose rate (AEDR), radium equivalent activity, internal and external hazard index of Jalingo and Wukari farms were evaluated and the result is found in Table 6. The absorbed dose rate and AEDR of the two locations were far above the safety limit of $59 \mathrm{nGy} / \mathrm{h}$ and $0.07 \mathrm{mSv} / \mathrm{y}$, respectively, as approved by [14]. The results obtained for both the $\mathrm{H}_{\text {int }}$ and $\mathrm{H}_{\text {ext }}$ were all above unity, which is of great concern both for the farmers and the community at large.

\section{Conclusion}

The average activity concentrations of ${ }^{238} \mathrm{U},{ }^{232} \mathrm{Th}$, and ${ }^{40} \mathrm{~K}$ at various farm sites evaluated in Jalingo were generally above the safety limits. In Wukari farm sites, the average activity concentrations of ${ }^{232} \mathrm{Th}$ were the only ones above the safety limit as approved by UNSCEAR (2000). The activity concentration of crops in both Jalingo and Wukari increases in the order ${ }^{40} \mathrm{~K}>{ }^{232} \mathrm{Th}>{ }^{238} \mathrm{U}$. However, the radionuclides hazard indices and cancer risk showed exposure risk for Jalingo. Hence, this may pose a radiological and cancer risk to farmers and residents in 
these study areas. The spatial analysis distribution for Excess Life Cancer Risk (ELCR) amongst the two areas established showed cancer risk, especially in Jalingo farmlands. There is a need to monitor the seasonal variation of radionuclide levels in the various sampling points in the studied areas and extend it to other communities around the area to make conclusive predictions on exposure levels. However, food crops from these locations must be well prepared before consumption to safeguard the health of the residents concerning thorium and uranium in the affected sites. It is also recommended that further studies on radioactivity should be carried out to cover the entire Taraba state to get baseline data for future studies.

\section{Conflicts of Interest}

The authors declare no conflicts of interest regarding the publication of this paper.

\section{References}

[1] Abdulaziz, A. and Taher, A. (2013) A Study on Transfer Factors of Radionuclides from Soil to Plant. Life Science Journals, 10, 532-539.

[2] Kolapo, A.A. and Omoboyede, J.O. (2018) Health Risk Assessment of Natural Radionuclide and Heavy Metals in Commonly Consumed Medicinal Plants in SouthWest Nigeria. Ife Journal of Science, 20, 529-537. https://doi.org/10.4314/ijs.v20i3.7

[3] Alausa, K.S., Odunaike, K. and Adeniji, I.A. (2017) Transfer Factor of Radionuclides from Soil-to-Palm Oil Produced from Elere Palm Tree Plantation Near Ibadan Oyo State, Nigeria. Nigeria Journal of Pure and Applied Physics, 7, 7-12.

[4] Alsaffar, M.S., Jaafar, M.S., Kabir, N.A. and Ahmad, N. (2015) Distribution of ${ }^{226} \mathrm{Ra}$, ${ }^{232} \mathrm{Th}$, and ${ }^{40} \mathrm{~K}$ in Rice Plant Components and Physicochemical Effects of Soil on Their Transportation to Grains. Journal of Radiation Research and Applied Sciences, 8, 300-310. https://doi.org/10.1016/j.jrras.2015.04.002

[5] Asaduzzaman, K., Khandaker, M.U., Amin, Y.M. and Mahat, R. (2015) Uptake and Distribution of Natural Radioactivity in Rice from Soil in North and West Part of Peninsular Malaysia for the Estimation of Ingestion Dose to Man. Annals of Nuclear Energy, 76, 85-93. https://doi.org/10.1016/j.anucene.2014.09.036

[6] Beretka, J. and Mathew, P.J. (1985) Natural Radioactivity of Australian Building Materials, Industrial Wastes and By-Products. Health Physics, 48, 87-95. https://doi.org/10.1097/00004032-198501000-00007

[7] El-Adl, A.M., Abd El-Hadi, A.H., Horeya, M.F. and Abdein, M.A. (2012) Molecular Genetic Evaluation of Seven Varieties of Summer Squash. Journal of American Science, 8, 41-48.

[8] Ekhaguere, O.A., Alatise, O.O. and Oyeyemi, K.D. (2019) Assessment of Natural Radionuclides in a Fertilized Farmland in Abeokuta, Nigeria: Implications for Environmental Radioactivity Evaluation and Monitoring. Journal of Physics. Conference Series, 1299, Article ID: 012093. https://doi.org/10.1088/1742-6596/1299/1/012093

[9] Harb, S., El-Kamel, A.H., Abd El-Mageed, A.I., Abbady, A. and Rashed, W. (2014) Radioactivity Levels and Soil-to-Plant Transfer Factor of Natural Radionuclides from Protectorate Area in Aswan, Egyptian. World Journal of Nuclear Science and Technology, 4, 4-15. http://www.scirp.org/journal/wjnst https://doi.org/10.4236/wjnst.2014.41002 
[10] Marko, S. and Smodis, B. (2011) Soil-to-Plant Transfer Factors for Natural Radionuclides in the Grass in the Vicinity of a Former Uranium Mine. Proceedings of the International Conference Nuclear Energy for New Europe, Bovec, Slovenia, September 12-15, 2011, $703 \mathrm{p}$.

[11] Ocheje J.A. and Alexander A.T. (2020) Determination of the Transfer Factor and Dose Rate of Radionuclide in Some Selected Crops in Kogi State, Nigeria. IOSR Journal of Applied Physics, 12, 7-12.

[12] Reeba M.J., Anilkumar, S. and Jojo, P.J. (2017) Ingestion Dose Due to Primordial Radionuclides in the Food Crops Grown in HBRA in Kerala. International Journal of Theoretical and Applied Mechanics, 12, 785-795.

[13] Samad, M.A., Haydar, M.A., Ali, M.I., Paul, D., Bhuiyan, M.M.R. and Islam, S.M.A (2012) A Study on the Radioactivity Level in Raw Materials, Final Products and Wastes of the Phosphate Fertilizer Industries in Bangladesh. Journal of Environmental Protection, 3, 1393-1402. https://doi.org/10.4236/jep.2012.310158

[14] UNSCEAR (United Nations Scientific Committee on the Effects of Atomic Radiation) (2000) Exposures from Natural Radiation Sources. Report to the General Assembly, with annexes, Annex-B, United Nations, and New York. UNSCEAR, Vienna, Austria. 